\title{
Leigh Hunt Sued for Debt by a Friend
}

\section{A V I D R. C H E N E Y}

Leigh Hunt, as is well known, seems never to have had enough money. He was frequently forced to appeal to his friends for help through the more difficult times. He borrowed from Shelley to go to Italy, ${ }^{1}$ from Byron to stay there, ${ }^{2}$ and from Colburn to return to England. ${ }^{3}$ Carlyle kept sovereigns ready on his mantelpiece to lend to him.. ${ }^{4}$ Even the Duke of Devonshire's resources were tapped. ${ }^{5}$ But Hunt never borrowed money he did not intend to pay back, and most loans not amicably canceled were eventually repaid.

On at least one occasion, however, Hunt found himself in serious legal difficulties over debt. The incident, referred to briefly and somewhat inaccurately by Louis Landré, ${ }^{6}$ occurred early in 1836 when Hunt was unusually hard-pressed financially. Leigh Hunt's London Journal had just collapsed, and Hunt's series of contributions to the New Monthly Magazine had not yet begun. No other projects were in hand. Mary Shelley and her son, Sir Percy, had not yet arranged the

1On January 25, 1822, Shelley sent Hunt $\& 150$ to help defray the cost of Hunt's journey to Italy. See Shelley's letter to Hunt dated January 22,1822 , in Frederick L. Jones, ed., The Letters of Percy Bysshe Shelley (Oxford: Clarendon Press, 1964), II, p. 379.

2See Leslie A. Marchand, Byron: A Biography (New York: Alfred A. Knopf, 1957), III, pp. 1081-82, 1085-86; and George Dumas Stout, "Leigh Hunt's Money Troubles: Some New Light," Washington University Studies 12 (1925), pp. 221$22,228$.

3See Edmund Blunden, Leigh Hunt: A Biography (London: Cobden-Sanderson, 1930 ), p. 220.

4See Francis Espinasse, Literary Recollections (New York: Hodder and Stoughton, 1893), p. 340 .

5 See Hunt's letter to the Duke of Devonshire dated January 11, 1844, in Sandford A. Strong, Critical Studies and Fragments (London: Duckworth and Co., 1905), pp. 176-78; and J. Payne Collier, "The Late Duke of Devonshire and Leigh Hunt," The Athenaeum (8 March 1862), pp. 330-31.

6Leigh Hunt (1784-1859): Contribution d lhistoire du Romantisme anglais (Paris: Société D'Édition, 1935), I, p. 204. 
quarterly payments on Shelley's intended bequest, ${ }^{7}$ and the government pension was still years away. ${ }^{8}$ At this desperate time, with no regular income and with eight children at home to support, ${ }^{9}$ Hunt was suddenly threatened with imprisonment if he did not immediately pay a debt of about $£ 50$. The blow was not only unexpected but hurtful, because the suit was brought by a supposed friend and was thus thought by Hunt to be a kind of treason.

The difficulty began in July, 1835, when Hunt applied for a loan to solicitor William Moxon, brother of Hunt's publisher Edward Moxon. Twice during the year Hunt borrowed additional sums. Then early in March, 1836, without warning, came the writ for $£ 43$ threatening arrest if Hunt did not pay the sum immediately. What followed is told in a series of letters ${ }^{10}$ between Hunt, the two Moxons, publisher Charles Knight, neighbor Thomas Carlyle, legal friend Thomas Noon Talfourd, cabinet member Lord Holland, and member of parliament John Bowring.

The writ itself and the letters exchanged during the first week of maneuvering have not been located, but what happened is made clear in the succeeding letters. Hunt immediately answered the writ from Moxon, stating his complete inability to pay and "appealing," as Hunt later put it, "to his humanity." In a return letter, Moxon suggested that $£ 30$ of the money could be obtained by allowing his brother Edward to sell, at a reduced price, the remaining volumes of The Poetical Works of Leigh Hunt which Edward Moxon had published in 1832. The suggestion put Hunt in a painful dilemma, since the unsold books were security for a $\& 100$ loan from Chandos Leigh, later Lord Leigh of Stoneleigh. ${ }^{11}$ Nevertheless, Hunt went to visit Edward Moxon on

$7 £ 30$ per quarter were paid to Hunt by Mary Shelley beginning in 1844 . See Blunden, Leigh Hunt, p. 294, and Landré, Leigh Hunt, I, p. 243.

$8 £ 200$ per year were paid to Hunt from the Civil List beginning in 1847. Blunden, Leigh Hunt, p. 297.

9The children were Thornton (1810-1873), John (1812-1846), Mary Florimel (1814-c.1845), Percy Bysshe Shelley (1817-1899), James Henry Sylvan (1819post 1863), Vincent (1823-1852), Julia Trelawney (1825-1872), and Jacintha Shelley (1828-1914).

10Acknowledgement for providing me with copies of the Leigh Hunt, Thomas Carlyle, William Moxon, Charles Knight, Vassall Holland, and John Bowring letters in their collections, and for permission to publish them, is made to the University of Iowa Libraries for document 1 and letters 1-15 and 17, to The British Library for letters 16 and 18, to Harvard College Library for letter 19, and to The Bodleian Library, Oxford, for letter 20. I am grateful to the College of Arts and Sciences of the University of Toledo for grants awarded by the Scholarly Activities Committee and for the Academic Affairs Research Grants which have provided funds for procuring copies of Leigh Hunt letters.

11First Baron Leigh (1791-1850), poet and author. His father James Henry Leigh, after whom Hunt was named, was privately educated by Hunt's father, Isaac Hunt. See Blunden, Leigh Hunt, p. 6. 
Friday, March 4, presumably to discuss the proposal. Unfortunately Moxon was not at home and it was not until Monday, March 7, that Hunt was able to see him. At that time Moxon apparently told Hunt, among other things, that the books would in time bring the $£ 100$ and that there was already some money on hand. Hunt apparently suggested he would write to Chandos Leigh for permission to sell the books in order to pay William Moxon.

In the meantime, Hunt's neighbor Thomas Carlyle had responded on March 3 with an immediate attempt to help. In January, Carlyle had sent Hunt a paper from an anonymous friend offering money after the collapse of the London Journal. ${ }^{12}$ Hunt had turned it down at the time. ${ }^{13}$ Now Carlyle renewed the offer and gave encouragement about the government pension for Hunt that Carlyle and others were working on.

Letter 1. Carlyle to Hunt. ${ }^{14}$

My Dear Sir,

Thursday Morning

Here is the old piece of Paper from the unknown Friend; with many satisfactions that it can do you a service. Courage!

I understand that there is decidedly hope of the Pension; that persons [of] all colours are striving in it, voting for it. A little while! Post nubila Phoebus!

\section{Ever affectionately}

T.C.

The earliest extant document dealing directly with the law suit is the declaration William Moxon sent Hunt on March 6, stating that he had filed an action of debt against Hunt, who must enter a plea within four days.

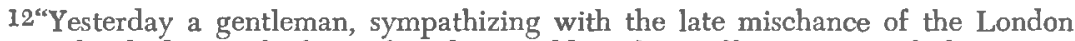
Journal, asked me, whether I thought I could, without offence to your feelings, hand you the inclosed little Paper on the part of a Nameless Friend?" MS letter dated Jan. 15, 1836, in the Beinecke Rare Book and Manuscript Library, Yale University.

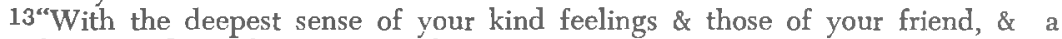
delight to find another jewel to hang in my memory with the thought of his offer, I trust that neither you nor he will think ill of me in seeing it come back." MS letter dated Jan. 24, 1836, in the Brewer Collection, University of Iowa Libraries, $\mathrm{fMsL} / \mathrm{C} 28 \mathrm{~g} /$ no. 20.

14MS letter in the Brewer Collection, University of Iowa Libraries, fMsL/ C28g/no. 23. Addressed to: Leigh Hunt Esqr/4. Upper Cheyne Row. Published by Charles Richard Sanders in "The Correspondence and Friendship of Thomas Carlyle and Leigh Hunt: The Early Years," Bulletin of The John Rulands Library, 45 (1963), p. 480. 
In the Kings Bench

\section{Between William Moxon Plaintiff and \\ Leigh Hunt Defendant}

Take Notice that a Declaration was this day filed against you with the Clerk of the Declarations at the Kings Bench office in the Inner Temple, London, at the Suit of the above named Plaintiff in an Action of Debt; and unless you Plead thereto in four Days from the date hereof Judgment will be signed against you by Default.Dated this Sixth Day of March 1836

\section{Yours \&c.}

Willm Moxon

To Mr. Leigh Hunt

$$
\text { In person }
$$

\section{the above named Defendant}

When two of the four days allowed by the Declaration had passed, Hunt sent his eldest son, Thornton, to William Moxon with a letter seeking an extension. Hunt needed, he said, additional time to receive an answer from Chandos Leigh as to whether he would give permission to sell the books at a discount. But, ironically, Hunt had been too embarrassed even to write to Leigh, as is made clear in later letters. However, by this time he had apparently consulted a legal friend, probably Thomas Noon Talfourd, for he also requested a copy of his first letter to Moxon in answer to the original writ. He wanted a complete set of documents concerning the affair. Naively he asked that the cost of the copy be added to his account with Moxon, that is, to the debt for which Moxon was suing him.

\section{Letter 2. Hunt to William Moxon. ${ }^{16}$}

Chelsea-March 8th. 1836

$\operatorname{Sir} /$

It was only yesterday that I learnt in Dover Street, ${ }^{17}$ that you were not in habit of constant communication with your brother. I went there the morning I received your proposal about the books, but he was out; \& I learnt that I could not see him next day (Sat-

15MS in the Brewer Collection, University of Iowa Libraries, fMs/H94ag/p. 6.

16MS letter in the Brewer Collection, University of Iowa Libraries, fMs/H94ag/ p. 7, in the writing of Leigh Hunt's wife, Marianne. Most of the Hunt letters in the series seem to be copies of the original letters.

17Edward Moxon lived at 44 Dover Street, Piccadilly, from 1833 to 1844. 
urday). I therefore said that I would send the day following to know if he could see me on Monday, \& he did so. I then told him I would write to $\mathrm{Mr}$ Chandos Leigh to ask his permission to use the books for the purpose required; but the letter which I have received from you meanwhile, \& which leaves me too little time to be sure of his answer, forces me to consult my friends to know what I am to do. I should be glad to know by the bearer, or by return of post (if you are not at your chambers when he comes), whether you propose to allow me no further time, \& for what reason, under all the circumstances, you deny it me, if so. I have to request also, that you will let the bearer copy the last letter I wrote you,-the one in answer to the writ I received; or if you are out, to send me a copy of it by return of post, \& add it to your account

To William Moxon Esq

$$
\begin{aligned}
& \text { I am, Sir, } \\
& \text { Your Obedt. Servant } \\
& \text { Leigh Hunt }
\end{aligned}
$$

Moxon's answer came back the same day carried by Thornton. It was a brief letter defending Moxon's action in a business-like way, but allowing Hunt six additional days in which to make his plea. It failed. however, to mention the letter of which Hunt had sought a copy.

\section{Letter 3. William Moxon to Hunt. ${ }^{18}$}

Sir,

I have received your Letter and I need only say that I consider, \& I believe every reasonable person would agree with me, that the manner in which I have been treated in reference to my account, affords a sufficient reason for the course I have adopted-I have no objection to allow you time to communicate with Mr Leighsay till Monday next [i.e., March 14].

I am Sir,

$$
\begin{aligned}
& \text { Your most obed. Servt. } \\
& \text { Willm Morion } \\
& \text { Southampton Buildings } \\
& 8 \text { March- }
\end{aligned}
$$

In his answer to Moxon's brief note, Hunt argued that he had not p. 9.

18MS letter in the Brewer Collection, University of Iowa Libraries, fMs/H94ag/ 
treated Moxon badly in connection with the account. He certainly had not ignored the original writ, but had made every effort to respond to Moxon though it had been difficult to find him. On the other hand, Moxon had been dilatory in responding to Hunt's original letter, even though Hunt was under threat of imminent arrest. Again Hunt's financial naiveté is apparent when he says Moxon should not have expected to be repaid, since he knew when he loaned the money that Hunt was a "pennyless man" and that he was in even worse straits now. He added that his friends considered that he was being treated harshly by Moxon, and thus Hunt felt emboldened to make a counter proposal concerning his Poetical Works. Instead of selling them immediately at discount prices as Moxon had suggested, they would be sold off normally with Moxon getting the proceeds until Hunt's debt was paid, thus leaving the bulk of the books to secure the debt to Chandos Leigh.

Letter 4. Hunt to William Moxon. ${ }^{19}$

Chelsea March 10, 1836

Sir,

If by "treatment" you mean inattention, I showed you in my first letter on this subject, that I had not knowingly been guilty of it:-not to mention that repeated calls have been made at your chambers, when neither you, nor any one else, was there to answer them. I did not receive your answer to my first letter till two days after it was sent, though a threat of instant arrest was hanging over me; and the day before yesterday when my son called with my second letter, the one in answer to your notice of "Declaration"-he was told that you had been there early in the morning, but were not expected all the rest of the day.

If "treatment" means the non settlement of your account, you knew, when you first undertook to see to these matters for me, that I was a pennyless man,-that I had no other money, as they proceeded, [?but] what I received as editor of the London Journal, which money was swallowed up by a large family and the payment of various instalments,-and that when the London Journal stopped, I was almost as pennyless as before, in prospect, and far worse off meanwhile except for eight weeks to come. You certainly had not lost by my connexion, though my account was not settled; and I thought at all events, that you would give me

19MS letter in the Brewer Collection, University of Iowa Libraries, fMs/ H94ag/p. 10. 
time, and I begged you to do so, and unquestionably understood that you meant to do it. Instead of this, you come upon me at the moment when you knew me to be most distressed in prospect, with a writ for $£ 43$ (the account says 33 ); and the account itself, instead of appearing to be that of a friendly solicitor, seems to be screwed up to every possible height of charge; so that time might be allowable for that reason only, to say nothing of the friendliness which I had supposed to be existing towards me.

Now, Sir, had I not received the notice of "Declaration," it was my determination to say nothing of all this to anybody, hoping that you would ultimately be sorry for having acted so hardly; and I was about to write to Mr. Chandos Leigh, with great pain, to ask his permission to make the required sale of the books. But the alarm into which this fresh proceeding threw me, forced me to recur for advice to my friends; and they are of opinion, that the whole of your proceedings towards me are unwarrantably harsh and cruel, including this very proposal about the books. Your brother tells me, that the books, if suffered to take their time, would unquestionably produce the whole hundred pounds for which they are a security to Mr. Leigh; while, if sold off immediately at the necessary undervaluation, they will fetch no more than the thirty pounds you speak of. Is it right and just in you to ask me to make such a sacrifice, \& to threaten me with imprisonment if I do not? The proposal they recommend me to make under the circumstances, is, that I should get Mr. Leigh's permission to hand over to you the proceeds of the books in the course of sale, till the whole of your account be liquidated, which will thus keep the main stock of them for him, and enable me both to make the request to him with a better grace, and be more secure of liquidating his debt also.

Therefore, accordingly, [I] make this proposal to you now, and will write to Warwickshire the moment I receive your acceptance of it. Your brother tells me there is some little money in hand, which of course you would receive at once.

Begging your immediate attention to this proposal, and again requesting that you will either let the bearer [i.e., Thornton Hunt] copy out my first letter to you, or send me a copy of it yourself ( $a$ request, of which no notice is taken in your last) I am, Sir,

Your obedt. Servant

Leigh Hunt

Moxon answered immediately, countering Hunt's statements and rejecting the suggestion about the books, since his brother had told 
him that only three copies had been sold in the past 18 months. He added that he would give Hunt the original of the letter he sought a copy of, but only after the suit was settled. Orally he told Thornton that he did not, as Hunt later phrased it, "chuse to put weapons into an enemy's hands."

\section{Letter 5. William Moxon to Hunt. ${ }^{20}$}

Sir,

I received your Letter of yesterday- As to the "repeated calls" made at my Chambers it is rather singular that I should not have heard of them before, as I am generally at Chambers the greater part of the day- I replied to your first Letter the moment I received it \& I delivered my answer to your 2 nd Letter into the hands of your Son.- With regard to the amount of my Claim, I refer you to the 3 accounts delivered-one on the 25th July last, a 2nd on the 7th of Oct. last, amounting to $£ 33.12 .8$, \& a 3rd on the 25th January last, amounting to $£ 41.19 .8$ - You are pleased to observe that my account "seems to be screwed up to every possible height of charge"- I will only say that this objection now comes with a very bad grace- You also observe that I undertook the business for you when you were "pennyless". I would ask you whether on that account, you ought not to have made an effort to pay me while you were receiving 8 Gnas per week? As to the Books-my brother told me, \& I understand he also told You, that there was not the slightest chance of their being sold in the "regular course of Sale" the number sold within the last 18 months being only 3 copies!! Had I not known this fact I should never have made any suggestion on the subject-if I were to agree to your proposition I should in all probability never receive my debt. I therefore, decline your proposition \& to put an end to discussion which will be useless, I beg that I may not be troubled further on the matter-

I will give you up the original Letter of which you require a copy, on the settlement of the action.-

I am Sir,

Yr. most obed. Servt.

Willm Moxon

33 Southampton Buildings,

Chancery Lane,

11 March 1836

20MS letter in the Brewer Collection, University of Iowa Libraries, fMs/H94ag/ p. $11 /$ no. 2 . 
On being told that Edward Moxon had informed his brother William that the books would not sell, Hunt wrote to Edward for clarification, since it had been his understanding that they would sell if given sufficient time.

Letter 6. Hunt to Edward Moxon. ${ }^{21}$

Dear Sir,

Chelsea March 12, 1836

When I saw you the other day in Dover Street [probably on Monday, March 7, 1836], you told me that the copies of my book would fetch Mr. Chandos Leigh's hundred pounds, if "a considerable time" were allowed them to sell off; and you added, that you were prepared to tell him so if spoke to on the subject (or as indeed you had originally undertaken to do). On asking you what portion of time you thought it would take, you said "some," or "several vears,"-I do not remember which.

Now as I have just received a letter from your brother Mr. William Moxon, (to whom I had made a proposal accordingly) in which he says he "understands" you to have told me, "that there was not the slightest chance of their being sold in the regular course of sale, the number sold within the last eighteen months being only 3 copies"; will you be good enough to state to me in writing, to the best of your recollection, what you actually did say, that I may be relieved from this painful appearance of disingenuousness? - You mentioned nothing to me of the 3 copies (probably to spare an author's self-love); but you did speak I think, of there being some little money in hand. Perhaps by "regular course of sale" your brother thinks I meant sale at the original price; but I only meant sale by degrees, of whatever sort, as distinguished from immediate sale in the lump. You may remember you made some rough guess at a calculation to the former effect, to see whether Mr. Chandos Leigh could be paid his whole hundred pounds in the long run.

Requesting your immediate answer, as a favour, I am, dear Sir Yours Truly

Leigh Hunt

Edward Moxon answered the letter the same day. The letter remains untraced, but judging from Hunt's answer, dated March 17,

21MS letter in the Brewer Collection, University of Iowa Libraries. fMs/ H94ag/p. 12. Addressed: To/Mr. E. Moxon. 
Moxon did not speak directly on the prospects of selling the books.

In the meantime, Hunt still had not written to Chandos Leigh when William Moxon's new deadline for making a plea passed on March 14. Consequently, on March 16, Moxon notified Hunt that a writ for $£ 50.2 .8$ (including debt and costs) would be put into the hands of the sheriff's officer the next day for execution.

\section{Letter 7. William Moxon to Hunt. ${ }^{22}$}

Sir,

I beg to inform you that the amount of the Debt \& Costs, for which Execution has been opened against you, is £50.2.8; \& unless the amount be paid tomorrow, I shall put the writ into the hands of the Sheriff's Officer, which, I need not inform you, will much increase the Costs. -

$$
\begin{aligned}
& \text { I am Sir, } \\
& \text { Your most obed. Servt. } \\
& \text { Willm. Moxon } \\
& \text { 33 Southampton Buildings, } \\
& \text { Chancery Lane, } \\
& 16 \text { March } 1836
\end{aligned}
$$

Leigh Hunt Esq:

On March 17, Hunt, it appears, was in the middle of a letter to Edward Moxon, informing him that he would let him know in a week or two what to do with the books, when he received the notice from William Moxon. The remainder of Hunt's letter turned into a complaint to Edward about his brother's cruel actions.

Letter 8. Hunt to Edward Moxon. ${ }^{23}$

Dear Sir,

Chelsea. March 17, 1836

There is a little inaccuracy in the beginning of your letter of Saturday last: ${ }^{24}$ for it was not "settled" on that day, that I should write to Mr. Chandos Leigh, at least not on my part; for I never had an intention of parting with a single one of the books without

22MS letter in the Brewer Collection, University of Iowa Libraries, fMs/ H94ag/p. 13. Addressed to: Leigh Hunt Esq/4 Upper Cheyne Row/Chelsea. Postmarks: 7 Nt 7/MR 16/1836; TP/Chancery La; 3; [blurred].

23MS letter in the Brewer Collection, University of Iowa Libraries, $\mathrm{fMs} /$ H94ag/p. 15/no. 1.

24That is, the letter of March 12 which remains untraced. 
first applying to him on the subject. All I came to you to know was, whether the promise of their sale was so slow, that I could in decency ask him to let me avail myself of their sale at once, in consequence of your brother's threat if I did not do so;- and whatever I should have done had not your brother sent me that Declaration which forced me to consult my friends, ${ }^{25}$ my impression certainly was, that although the sale would still be slow enough, it would take "some" or "several" but not "many" years, especially as I understood you to say, if my recollection does not deceive me, that the price could be lowered still, which might possibly sell the the [sic] volumes better.

I will let you know in the course of a week or two,-or rather will consult you to let me know, what I can best do with the books for Mr. Leigh's advantage; or in case you are finally of opinion that the books really will not sell at all, and at any price (so to speak,-that is to say, so that out of my own miserable prospects I may as well reckon upon laying by three or four guineas a year for the liquidation of the debt) I will thank you to let me know that opinion by the bearer, or by return of post, in case I can still undergo the pain of applying to $\mathrm{Mr}$. C[handos] L[eigh] that is to say, in case your letter will still give me time to do it in; for I have this morning received a lawyers letter from him [See letter 7 above], in which he says that unless the money is paid to day, he shall put the writ into the hands of the Sheriff's officer.

I hope, in charity to himself, that he himself is hard driven for money, before he can treat me as he has done under all the circumstances; otherwise, to say the least of it, his conduct is not such as either a kind or far-sighted brother, I conceive, can contemplate with satisfaction; I mean, not such as is calculated to procure friends for a beginner of the world.

As to myself, it is utterly out of my power to pay the money to day; and if the Sherriff's [sic] officer must take me from my family, he must. May God forgive those who inflict this cruelty upon a man beset with difficulties and ill health.- I am, dear Sir

\section{Yours Truly}

Leigh Hunt.

To

Mr. Edward Moxon.

\&c. \&c.

25Probably Thomas Carlyle, Thomas Noon Talfourd, Charles Knight, John Forster, and Charles Cowden Clarke, all of whom are mentioned in letters involved in the suit. 
P.S. Your brother refuses me a copy of a letter I wrote him detailing the circumstances in which I stood towards him, and appealing to his humanity,-alleging that he "does not chuse to put weapons into the hands of an enemy!!" This answer he gave my son. ${ }^{26} \mathrm{I}$ beg you to think what this says on the subject.

Hunt also wrote to William Moxon on March 17, acknowledging receipt of Moxon's letter of March 16, which stated that if the debt was not paid on March 17 the writ would be placed in the hands of the sheriff's officer. The letter also answered in considerable detail William Moxon's letter of March 11 and asked him, amusingly in the circumstances, several legal questions concerning the suit which, as Hunt said, he would not bother him with if he "had any solicitor besides yourself."

Before Hunt could send either letter, it seems that he was advised by a friend that he should give in to William Moxon rather than go to prison. Consequently Hunt added a postscript to William Moxon's letter, accepting his original plan of selling off Hunt's book at a discount in order to pay the debt.

\section{Letter 9. Hunt to William Moxon.27}

Sir,

Chelsea-March 17, 1836

Just as I was about to write this letter, I received yours of yesterday. It is proper however that I should still write it, in order that I may answer your previous one [i.e., Letter 5 above], \& also put a question to you which you will answer in common humanity (if you have it).

I enclose a copy of the letter I received from your brother, ${ }^{28}$ \& have underlined the passage which I construed into an intimation that this letter [?matter] might still be settled amicably.

As I find I was mistaken in coming to this conclusion, I have to say in reply to your letter, that I am as loth to "trouble" as be troubled on this occasion, \& that it is somewhat strange you should tell me not to "trouble" you, who are giving me something a great deal more than trouble; and secondly, that in answer to

26The answer was presumably given to Thornton Hunt when he delivered Letter No. 2, above, to William Moxon.

27MS letter in the Brewer Collection, University of Iowa Libraries, fMs/H94ag/ p. $16 /$ no. 1 .

28Apparently the letter of March from Edward Moxon which remains untraced. 
your question, why having been pennyless when I first knew you, "I did not make some effort to pay you while I was receiving (subsequently) eight pounds per week," no man knew better than yourself how difficult it was for me to meet the instalments which I had to pay already, and some of which you were employed in helping me through,-knowing at the same time that I had all my children on my hands, ${ }^{29}$ and probably also (at any rate you know it now) that I could not go on with their education as I ought, nor even properly clothe them.

As to your refusal twice over, to let me have a copy of one of my letters, I ask you what does this tell? My son informs me, that you gave as a reason for your refusal, that you did not "chuse to put weapons into an enemy's hands!" What does that tell? I wish to screen nothing in the business from first to last. Why should you? I now again apply for a copy of that letter, in order that my friends and my lawyer (if I must be compelled to have recourse to one) may have the whole circumstances before them.

Finally, I have to ask, what are the precise measures you now threaten me with, and what time, or no time, I shall be able to have for settling with you, upon going through the expense (as it seems I must) of letting the law take its course. I have not yet applied to a solicitor, though I have consulted a legal friend, ${ }^{30}$ and shall have others to consult. I would avoid an application to a solicitor, if I can, and therefore I ask you as a matter of common humanity to myself, and of no ill intention towards you, what it is you mean to do; that is to say, whether to take my goods, or send me to a lock-up-house, and what time I can obtain for paying a sum impossible at present for me to discharge, by going to some further expenses. If I had any solicitor besides yourself, I should not trouble you with these questions; and under the circumstances, I trust you will not consider it reconcileable with common humanity to refuse me an answer to them. With respect to the copy of the letter, I have been told that I have a right to demand it, or [Pon] payment of the expenses of a copy and I do not understand how, in common candour and justice, you can withold it. All the other papers, including the "Declaration" are in my possession; and of the one, which you withold and which was an appeal to your humanity, I must set down the particulars to the best of my recollection, if you still refuse to let it be forthcoming.

29See note 9 above.

30Probably Thomas Noon Talfourd. 


\section{I am, Sir, \\ Your Obedt. Servant \\ Leigh Hunt.}

P.S. (Half past eleven)

Since writing the enclosed, I have been advised to part with the books at once, and throw myself upon the kindness of $\mathrm{Mr}$. Chandos Leigh; and I have written to your brother accordingly, to beg him to do so, and pay the proceeds into your hands.

A brief note (Letter 10 below) telling Edward Moxon to go ahead and sell the books according to his brother's suggestion was also enclosed with the letter of March 17 to Edward Moxon (Letter 8 above). This, in spite of the fact that Hunt had just written in the main letter that he "never had an intention of parting with a single one of the books without first applying to [Chandos Leigh] on the subject."

Letter 10. Hunt to Edward Moxon. ${ }^{31}$

\section{Dear Sir,}

\section{Chelsea-March 17, 1836}

Since writing the enclosed, I have been advised considering the state of my health and circumstances, to let the books be sold according to your brother's proposal, and I now write this second letter to tell you so, and to beg you to be good enough to sell them accordingly, and hand over to him the proceeds.- I must throw myself upon the kindness of Mr. Chandos Leigh.

Yours Truly dear Sir,

Leigh Hunt

William Moxon seems to have answered Hunt's letter of March 17, accusing Hunt of "twirling and turning" his brother's letter (which Hunt had sent him underlined at the appropriate place) and of trying to evade the sheriff's officer. Unfortunately, neither of the Moxon letters has been traced. But on March 19 Hunt answered William Moxon's letter, denying the accusations and offering once more to sell the books or to pay off the debt at $£ 5$ per quarter. In a postscript he reveals that his wife Marianne carried the letter and that he wished additional time to consult with Charles Knight about ways of raising money to pay the debt. ${ }^{32}$

31MS letter in the Brewer Collection. University of Iowa Libraries, fMs/ H94ag/p. 8/no. 2.

32Charles Knight had been publisher in 1835 of Hunt's "Captain Sword and Captain Pen" and of the second volume of Leigh Hunt's London Journal. 
Sir,

Saturday

Ungenerously as you have treated me, \& ungenerously as you are still able and apparently inclined to treat me, it is nevertheless due to my feelings and self respect to repel with indignation, the hint you have given me that I did not mean to pay you, and the charge you bring against me of "twirling and turning" your brother's letter. I have "twirled and turned" nothing;-the tendency to the belief is in your mind, and has nothing to do with mine:-and as to the intention of non-paying, the very first man to whom I voluntarily proffered an instalment, when $X$ had it in my power, \& with them I have kept it up, though to continue the payment greatly distressed me, was one who never gave me a threat, and it was for that reason I went to him first, with the first money I got into my hands.

If by asking what you meant to do, you fancied that [I] intended to evade the sheriff's officer, you are mistaken. I have never done so when similar calamities have befallen me, and I never shall. I never even deny my being at home to any body. And again ask you, therefore, in common humanity, to let me know; in order that I may avoid, if possible, the expense of going to another lawyer. I ask you also whether the books cannot still be sold; \& once more, whether you will accept my repeated offer of the $5 \&$ a quarter. The kind hearted man to whom I allude accepts $£ 3$ a quarter. I owed him a debt of $£ 25$. He is a tradesman of the name of Jackson, and resides at Knightsbridge.

$$
\begin{aligned}
& \text { I am, Sir, } \\
& \text { yr. obt. Servt. }
\end{aligned}
$$

L. H.

P.S. Mrs. Hunt brings this letter, \& will tender you a request that you will [three illegible words] give me time to consult $\mathrm{Mr}$. Knight, \& see what can be done [?toward] paying [four illegible words].

However, from the time his brother had informed him that only three copies had been sold in the last eighteen months, William Moxon had dropped the idea of getting his money by forcing Hunt to sell the

33MS letter in the Brewer Collection. University of Iowa Libraries. fMs/ H94agr/p. 14. 
books. So he rejected the plan explicitly in a brief note to Hunt on March 19.

\section{Letter 12. William Moxon to Hunt. ${ }^{34}$}

Sir,

I beg to decline having any thing to do with the Books- My proceedings have been, \& shall be straight forward-

$$
\begin{aligned}
& \text { I am, Sir, } \\
& \text { Your most obed. Servt., } \\
& \text { Willm. Moxon } \\
& \text { 33 Southampton Buildgs } \\
& \text { Saturday Morng-19 March }
\end{aligned}
$$

Leigh Hunt Esq:

Not having heard from Knight, and with all other immediate prospects for relief having been exhausted, on March 24 Hunt wrote a final pleading letter throwing himself on Moxon's mercy and begging him to accept the offered $£ 5$ per quarter.

Letter 13. Hunt to William Moxon. ${ }^{35}$

\section{Sir/}

\section{Chelsea March 24th 1836}

We have done whatever we could to procure you the money for your account, but in vain, \& know not which way to turn unless we absolutely beg it of friends to whom we are already indebted for existence, \& whom every delicacy renders it most painful to apply to.

We must really throw ourselves upon your mercy. Why will you not save an anxious family from the most wretched feeling by consenting to take $£ 5$ a quarter? Solicitors often do not get their money so quickly; and as the only proof I can give you of your security you may, if you please, receive the whole $£ 25$ every quarter from the bankers, \& I will send to you for the $£ 20$ on the second day of the month. If you do not chuse this, \& will consent to receive it otherwise, I will engage, upon my honour as a gentleman, to send the $£ 5$. for you on that day regularly every three

34MS letter in the Brewer Collection, University of Iowa Libraries, fMs/ H94ag/p. 16/no. 2. Addressed to: Leigh Hunt Esq:/4 Upper Cheyne Row/Chelsea. Postmarks: T. P./Chancery La: 2 AN 2/[?] 19/1836; [blurred].

$35 \mathrm{MS}$ letter in the Brewer Collection, University of Iowa Libraries, fMs/ H94ag/p. 17. 
months, commencing with it on the $2 \mathrm{~d}$ of April to any place you may be pleased to appoint.-to your brother, if you like it.

\section{I am Sir, \\ Your most obedient Servt. \\ Leigh Hunt}

Unknown to Hunt, however, Knight had already given some help. In his letter to Knight, Hunt had proposed that Knight publish a volume of reprints to be selected by Hunt from the newly defunct London Journal and that Knight advance him $\& 10$ on the project to be paid to Moxon. Unfortunately, Knight had not received Hunt's letter until March 23, when he wrote a note to Hunt explaining that Hunt's proposal was not acceptable but that he had already paid $£ 50$ to Moxon for the copyright on Hunt's Poetical Works and was ready to help further if Hunt could suggest an appropriate project.

\section{Letter 14. Knight to Hunt. ${ }^{36}$}

My dear Hunt,

I am very sorry to hear of the dilemma in which you are placed, -and that not on your account alone.- Till I have seen C[harles Cowden] Clarke I can only tell you that I paid Mr. Moxon £50,which was a great deal more than I ought to have paid for the assessment of your Copyright- I cannot think he will proceed to extremities with you-and if he does, or is inclined to do so, certainly a payment of $£ 10$ would not prevent him.

I wish you could vigorously make up your mind to do something. There are certainly matters in which I could be useful to you,-but the thing must in a great degree depend upon yourself. I have so many claims upon me that the horrid quid pro quo must enter into my desire to be of assistance even to you. Your notion of Reprints from the Journal would not answer. I am ready to go on with the Sheets!-

\section{Yrs most truly \\ Chas Knight}

\section{March 23rd}

I have only just now ( 6 o'clock) received your letter.-

Louis Landré says, "L’affaire s'arrange, grâce á Charles Knight qui verse á Moxon ce qui lui est dû." ${ }^{37}$ Unfortunately Knight’s help was

36 MS letter in the Brewer Collection, University of Iowa Libraries, fMs/ H94ag/p. 11/no. 1 .

37Landré, Leigh Hunt, I, p. 204. 
not sufficient to prevent the sheriff's officer from executing the writ, for as A. St. John Adcock says, and Hunt admits, there was "an execution in the house." 38 However, other help was on the way. Hunt had written to Lord Holland to solicit his aid toward a government pension, specifically to speak to Prime Minister Lord Melbourne in favor of it. Holland, though not optimistic, agreed to do what he could.

Letter 15. Holland to Hunt. ${ }^{39}$

\section{Private \& Confidential}

24 March-

\section{Dear Sir}

I cannot but be gratified not only with the kind feelings \& proofs of confidence which your letter conveys but with the prospect of any revival of former intercourse, of which though rare \& slight I retain a very pleasing recollection- Would to God this pleasure had less alloy in it- I am sadly concerned to find that your literary talents \& able \& persevering efforts in a good cause have met with a very inadequate reward from the publick \& that you are constrained to look to a pension- I lament this the more because I am sadly afraid its a very precarious resource \& very hard to attain \& can at any rate be only limited \& scanty if obtained at allIt grieves me to say so much to damp your hopes-but I am persuaded you are too well aware of the reduction of the funds allotted to pensions of this kind, to mistake a want of power for a want of will or to misconstrue any discouraging expressions I may use into indifference or insensibility to your fair and honourable pretensions- At least to the immediate request you make I can reply in an unqualified affirmative. Should your name be mentioned before me to my colleagues (\& I will add whether it be so mentioned or no) I will say to Ld. Melbourne all I think \& feel in favor of bestowing the first pension of the kind at his disposal upon you- He must know and approve of your history \& your works too well, to require my testimony, but I shall not fail to remind him that your claims are three-fold, as a man of letters, a friend in politicks \& a sufferer in the cause of Reform. Having said this, it will be unfair to him not to acknowledge that even if he is as sincerely impressed as myself with the propriety \& pleasure

38Famous Houses and Literary Shrines of London (London: J. M. Dent and Sons, Ltd., 1912), p. 292. See postscript to Letter 19 below.

${ }^{39} \mathrm{MS}$ letter in the Brewer Collection, University of Iowa Libraries, MsL/ H735h/no. 1. Published by Luther A. Brewer in My Leigh Hunt Library: The Holograph Letters (Iowa City, Iowa: University of Iowa Press, 1938), p. 297. 
of complying with your wishes, it may yet be impossible for him to do so- It would be perhaps equally unfair to you, by not apprizing you beforehand that such difficulties may occur to mislead you with hopes that may never be realized-I will do all I in propriety can to further your wishes-but I am not sanguine of success though I do not despair- In short I will try but I cannot undertake to succeed-

\author{
I am Dear Sir \\ with sincere good wishes \& \\ great regard \\ your obt. Servt. \\ Vassall Holland
}

Carlyle wrote to the author John Sterling on April 12: "By the bye, Jeffrey [i.e., Lord Jeffrey] has taken Hunt's pension in hand: may he prosper in it!"40 Also, John Bowring, a member of parliament, had become interested in Hunt's plight and had become part of the drive to get Hunt a pension from the government. On April 4 he wrote from Paris that he was returning to London the next week and would work "busily" on Hunt's behalf.

Letter 16. Bowring to Hunt. ${ }^{41}$

My dear Sir

Paris 4 April 1836

I will on my return to England occupy myself busily \& cordially in your service. It shall be alone or in cooperation as may appear best. I shall certainly say to others more than I could venture to say to you of your multitudinous claims. My purpose is to be in town by the middle of next week \& I shall be glad to see yourself or any friend of yours any morning before $11 \mathrm{oc}$.

I am my dear Sir

Yours very sincerely

Leigh Hunt Esq.

John Bowring

True to his word, Bowring visited Lord Melbourne only days after returning to England.

40Alexander Carlyle, ed., New Letters of Thomas Carlyle (London: John Lane The Bodley Head, 1904), I, p. 6.

41 MS letter in the British Library, Add. MS. 38,109, fols. 153-154v. Addressed to: Leigh Hunt Esq/4 Upper Cheyne Row/Chelsea/John Bowring. Postmark: 2 An 2/AP 8/1836. 
My dear Sir

I have to day had a good deal of conversation about you with Lord Melbourne-who is very favorably disposed. You will be most welcome any morning ( $\mathrm{I}$ breakfast at 9 oc if you will take tea \& toast with me)-before I go out which is usually about 11 oc Ever and truly yours

John Bowring 20 Ap! 1836

Leigh Hunt

1 Queen’s Cresc. [?]

Chelsea

Lord Melbourne shortly agreed that Hunt should be given a Royal Grant immediately, but Bowring thought that Hunt should discuss with his friends, apparently Carlyle, John Forster, and Talfourd, whether he should accept the sum, since it might jeopardize the awarding of the pension which was under consideration.

Letter 18. Bowring to Hunt. ${ }^{43}$.

\section{House of Commons \\ 11 May 1836}

Dear Sir

You will have heard of the intentions of Lord MelbournePerhaps it would be judicious to advise with your friends before you accept or reject the offer. We have obtained the signature of some twenty MPs to a memorial to Lord Melbourne \& we shall get no doubt 50 or 60 of the best names. It will be very important to ascertain whether the acceptance of the sum now offered-or how far its acceptance-would prejudice the pension question

Ever \& truly yours

Leigh Hunt Esq.

John Bowring

In the meantime Hunt had had to pay $£ 20$ in fees and keep of the officer executing the writ and another $£ 20$ on the debt to William Moxon by May 21, when he wrote to Talfourd concerning the matter

42MS letter in the Brewer Collection, University of Iowa Libraries, MsL/B78h. Published by Brewer in The Holograph Letters, p. 216.

43MS letter in the British Library, Add. MS. 38,109, fols. 155-155v 
and expressed a wish to bring together Talfourd and Carlyle, who were both working on the pension for him.

Letter 19. Hunt to Talfourd. ${ }^{44}$

My dear Talfourd,

4 Upper Cheyné Row-ChelseaSaturday-May 21

I said I would send the enclosed to Forster ${ }^{45}$ to beg your kindness in taking charge of it for me under existing circumstances; but it has struck me, that to save all possible chances of loss \&c. to so precious a document, I had better transmit it through as few channels as possible; so it comes to you at once.

Always fearing to trouble you, \& yet loving \& enjoying your kindness towards me, I am

\section{Ever truly yours, \\ Leigh Hunt}

P.S. Would you have any objection to my bringing Carlyle to your acquaintance \& house on Thursday evening? ${ }^{46}$ You know him,-the translator of Wilhelm Meister, ${ }^{47}$ \& writer of many deeply-thinking articles in the Foreign Quarterly and Edinburgh Reviews. He has a great respect for the author of Ion, \& would, I am sure, be much pleased to know him. He is also intimate with Jeffrey, \& has met Wordsworth. Could you oblige me with a ticket of admission for him?

I believe I said yesterday that the execution has been in my house five weeks, but I should have said eight. I was thinking of another date. His keep, \& fees, \& fees to the officers, have cost me already $£ 20$, which I have paid; and $£ 20$ have been paid of the debt, leaving upwards of $£ 30$. I know not exactly how much; for the $\& 5$ which the sheriff's officer mentioned to me when he first came, must I think have been absorbed in the subsequent payments, at least some of it.

44MS letter in the Houghton Library, Harvard University, MS Eng 883 (II 278). Addressed to: Mr. Serjeant Talfourd, M. P./ Elm Court,/ Temple/or/ Russell Square/ Private.

45Likely Lord Melbourne's offer of a Royal Grant. See Letters 18 above and 20 below.

46This was the evening (May 26) on which Talfourd's play Ion was first produced. Unfortunately illness prevented Hunt ("I could shed tears of vexation") from going. See MS letter Hunt to Forster dated May 21, 1836 in the Huntington Library, TA 40.

47Carlyle's translation of Goethe's Wilhelm Meisters Lehrjahre was published anonymously in 1824; the Wanderjahre appeared in 1827 in the collection entitled German Romance. 
P.P.S. This letter of course does not look [for an answer] ${ }^{48}$ previously to Monday,-except in what affects Carlyle; \& a verbal message will do, if you see my son.

On May 30, 1836, after three months of agony, Hunt was finally relieved of his plight. Talfourd, Carlyle, Forster, and Jeffrey seem to have agreed that since they could not hope for both the royal grant and a pension, the offered grant ${ }^{49}$ should be accepted in order to get Hunt out of his immediate difficulties rather than rely on the possibility of a future pension. Consequently, Carlyle wrote to Hunt on May 29 explaining the details of how the money was to be acquired and paid the next day.

Letter 20. Carlyle to Hunt. ${ }^{50}$

My Dear Sir,

Sunday Night 11 o'clock

I had a long conversation with Mr Talfourd; whom I found to be a most polite humane man, exceedingly well disposed towards you.

After much frank communication, both of us agreed that of the two Schemes the one suggested by Jeffrey did seem the hopefuller; that as both could not be followed, this latter must for the present be exclusively aimed at,-in the track and by the methods which Mr Talfourd and other Friends had already decided on.

The grand point for the moment being that you should have the means of meeting this existing perplexity. I took pains to ascertain how you were to act so that the result (of getting money to pay the debt, tomorrow morning) might be "infallible." This was the manner of procedure,

That you were to call at Mr Foster's [sic] ${ }^{51}$ tomorrow morning at 10 o'clock; when Mr F., furnished with Lord Melbourne's Letter and instructions how to act, would go with you, and get what money ( $£ 35$ or $£ 40$ ) might be needful; the remainder to be put into some Bank, to lie there as a nucleus for the Subscription, which ought thereupon to be directly proceeded with.

Knowing the pressure of the case, and to secure "infallibility,"

48Letter mutilated.

${ }^{49}$ Apparently one of the two times Hunt received royal grants of $£ 200$. See "Hunt, Leigh," DNB, v. 10, $1967 \mathrm{ed}$.

50MS letter in the Bodleian Library, Oxford. Published by Sanders in "Correspondence of Carlyle and Hunt," pp. 481-82.

51Carlyle consistently misspells Forster's name throughout the letter.

[55] 
I obtained farther that if you missed Mr Foster, or if by any accident Mr Foster and you could not obtain the money, then Mr Talfourd (who, or some substitute for him, was to be at the Court of Common Pleas) would himself advance the money on the security of that Letter.

I am in great haste. I write this down that the servant may carry it to you at 6 tomorrow morning. There was nothing more to be said, even if I had seen you tonight. Good night my dear Sir.

\section{Yours always}

T. C.

Thus once more Hunt had avoided prison, and in spite of the desperateness of his financial situation he seems to have kept his customary serene view of the world and his friends. 